\title{
Analysis of the time efficiency of skidding technology based on the skidders
}

\author{
Lukáš Orlovský*, Valéria Messingerová, Zuzana Danihelová \\ Technical Univerzity in Zvolen, Faculty of Forestry, T. G. Masaryka 24, SK - 96001 Zvolen, Slovak Republic
}

\begin{abstract}
The time efficiency and principles of ergonomics related to timber skidding are based on the time consumption per work cycle as well as on the time consumption per individual work operations. Regarding the demands on the environmental requirements and ever increasing cost of work, it is necessary to objectively evaluate the inevitable time consumption required for timber skidding using all technologies. The paper summarised the results of time studies for skidder technologies. The time study compares the time consumption and productivity of cable skidders and cable-grapple skidders, with the main focus on developing time prediction models. The main aim of the study was to objectify the skidder time consumption and establish the impact of production factors on the time consumption of partial work operations of skidders. Within the time study 231 work cycles were measured, and 53 snapshots of work day with using methods continual time study. The overall time consumption of the work cycle and gross production rate of the monitored cable and cable-grapple skidders is affected by the following production factors: the skidding distance, volume of skidded logs and number of skidded logs. The impact of individual production factors on the overall time consumption of the work cycle is different for each group of skidders. Non-operation times of the skidder operators' shifts represent $24.6 \%$ with the highest part taken by the technical operation of the work place. The mean gross production rate of the monitored skidders varied from 33.3 to $6.91 \mathrm{~m}^{3} \mathrm{~h}^{-1}$.
\end{abstract}

Key words: time consumption; time study; wheeled skidders; time prediction models; productivity

Editor: Vladimír Šebeň

\section{Introduction}

Tractor technologies belong to the most often used for timber skidding in the forests of the Slovak Republic. According to the Green Report from 2007, tractor reached $78 \%$ (the last official record) of the technologies used, thereof skidders $47.6 \%$. Most of them are cable skidders of the types LKT 81 and LKT 81T. However, other types of skidders, e.g. grapple and clambunk, are used for timber skidding worldwide (Borz et al. 2014a).

Present day performance standards (PS) for skidder technologies published in the proceedings no. 24 of the Ministry of Agriculture and Rural Development of the Slovak Republic are not current and outdated (last issue from 1992). They do not correspond to the current development of forestry equipment and requirements for modern skidders regarding ergonomics and ecology, since various forestry entities (e.g. state enterprise LESY SR) use their own internal performance standards and rules for wages of workers in logging. The time studies into skidders were discussed by many authors in various countries with the aim of determining the impact of various production factors on the productivity and the amount of costs, or with the aim of comparing various skidding methods (winch versus grapple) in various terrain and stand conditions (Proto et al. 2018). Abeli (1996) in his study compared the productivity and costs of three skidders at the Sokoine University. The research results have shown that the differences among skidders were affected significantly by the size and type of the machine, skilfulness of the operators and the stand slope inclination. Kluender et al. (1997) studied the productivity of skidders equipped with cable winch and skidders equipped with hydraulic grapple in the pine forests of the USA. The study came to a conclusion that grapple skidding technology is significantly faster and more productive than skidders with a cable winch. The same results are presented in the study of Mederski et al. (2010) studying the productivity of cable and cable-grapple skidders in the Northern Poland. The results have shown that cable-grapple skidder HSM with hydraulic crane achieved two times higher productivity when compared to the RSG skidder equipped with cable winch. Naghdi et 
al. (2008) compared the skidding productivity of skidders in the conditions of incidental felling and regeneration felling in the company Shafaroud. They found out that the productivity in the case of regeneration felling was higher by $47.7 \%$ than in the case of incidental felling. Most of the time studies from abroad were focused only on one type of skidders (Behjou et al. 2008; Zečíc et al. 2011; Mousavi 2012a; Mousavi 2012b; Borz et al. 2013; Kulaket al. 2013; Nikooy et al. 2013; Marčeta et al. 2014; Borz et al. 2015; Proto et al. 2018; Kulak et al. 2019), or on several tests carried out using various forestry technologies and equipment (Bavaghar et al. 2010; Spinelli $\&$ Magagnotti 2012). Regarding the production factors these studies were focused only on the mean volume of skidded logs ranging from 1.05 to $5.34 \mathrm{~m}^{3}$ with the mean skidding distance up to $400 \mathrm{~m}$ (Sabo \& Poršinsky 2005; Behjou 2010; Ghaffarian et al. 2013; Mousavi et al. 2013; Kulak et al. 2017; Proto et al. 2018). In the case of further time studies (Zečíc et al. 2010; Lotfalian et al. 2011; Borz et al. 2013, Borz et al. 2014b; Borz et al. 2015) the skidding distance was more than $800 \mathrm{~m}$.

Evaluating the efficiency in timber logging and timber transportation for various forestry equipment and technology is carried out using the time study (Björheden et al. 1995; Acuma et al. 2012), which is conducted in order to express the consumed time and carried out production related to the relevant impact of factors. From the methodological point of view, there are two types of time studies: correlation studies and comparative studies. Correlation studies are carried out in order to find out the relationship between the work time consumption and factors determining the work, while the aim of comparative studies is to compare the time consumption or productivity of various machines or methods of work used to complete the same task (Mousavi et al. 2013). The results of time studies were mostly used for determining the extent of production and its rationalisation (Björheden 1991; Sarikhani 2001; Nurminen et al. 2006) or for assessing various logging methods in order to find the most economical one. The aim of the present study was to: (i) assess the impact of production factors on the time consumption of individual partial work operations of cable and cable-grapple skidders; (ii) develop models for predicting the time consumption of partial work operation of skidders; (iii) find out and compare the productivity and efficiency of the tested skidders.

\section{Material and methods}

\subsection{Study location}

Study of the time consumption was carried out in the University Forestry Enterprise of the Technical University in Zvolen from 23 May to 25 October 2019 in 20 stands mostly beech, beech-fir and beech-oak. During the study 53 snapshots of the work day were taken and 231 work cycles of skidders were measured. Following skidders were observed and tested within the study: cable-grapple skidders (HSM 805HD, LKT 81 ITL (HC) with hydraulic crane, EQUUS 175N) and cable skidders (LKT 81 ITL, LKT 81T). Working groups included from two (LKT 81 ITL, EQUUS 175N) until three members for every skidder. Figure 1 and 2 illustrate the tested cable and cablegrapple skidders. Table 1 presents the characteristics of the production factors of forest stands where the timber skidding was carried out, while Table 2 describes the characteristic parameters of individual monitored skidders analysed within the study.

\subsection{Work phase classification}

The overall time of the work cycle of skidder operators was divided into following partial work operations:

- Unloaded travel from the forest landing into the stand: the phase begins with the skidder movement from the forest landing towards the stand and finishes when the skidder reaches the cut stems.

- Cable releasing: Initiating the subsequent work operation is preceded by terminating the previous one. The operation begins by releasing the cable from the skidder winch drum and terminates when the choker setter reaches the logs to be skidded.

- Collecting time: the operation begins when the choker setter fastens the logs to the chokers and finishes when he steps back to a safe distance from the log.

- Winching the load from the stand to the skidding line: this phase starts with winching the cable on the
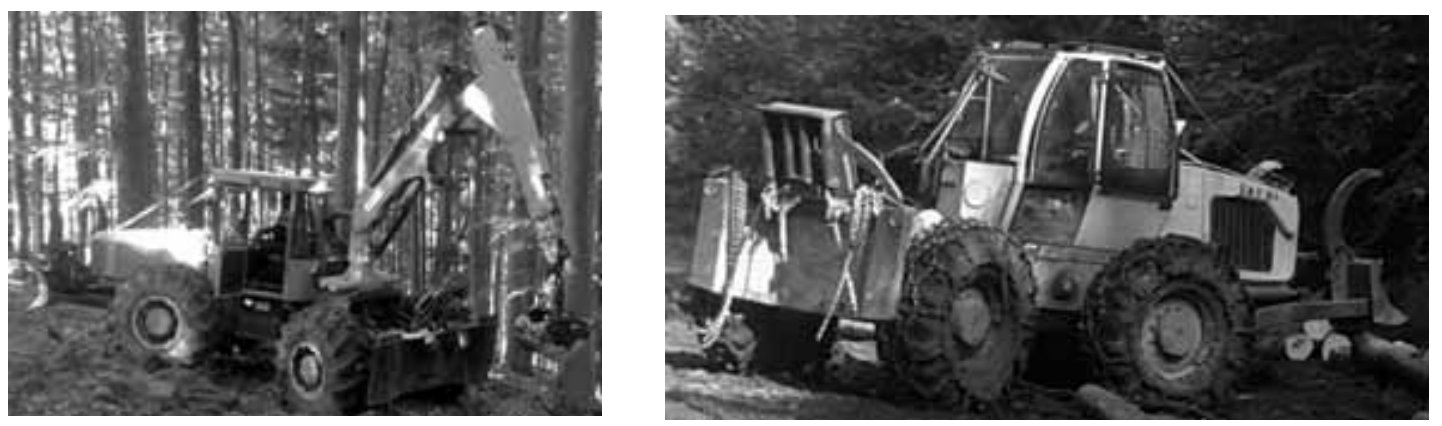

Fig. 1 and 2 on the left EQUUS 175N (cable-grapple skidder) and on the right LKT 81 ITL (cable skidder). 
Table 1. Characteristics of production factors of study stands.

\begin{tabular}{|c|c|c|c|c|c|c|}
\hline \multirow{2}{*}{ Subcompartment } & \multirow{2}{*}{ Type of skidder } & Skidding distance & Winching distance & \multirow{2}{*}{$\begin{array}{c}\text { Slope inclination } \\
{[\%]}\end{array}$} & Volume of skidded stems & Mean tree volume \\
\hline & & & & & \multicolumn{2}{|c|}{$\left[\mathrm{m}^{3}\right]$} \\
\hline 1318 & HSM 805HD & 424 & 21.2 & 30 & 53.46 & 2.10 \\
\hline 1322 & HSM 805HD & 87 & 8.8 & 35 & 24.14 & 1.55 \\
\hline 1315 & HSM $805 \mathrm{HD}$ & 1,099 & 18.0 & 35 & 37.04 & 2.20 \\
\hline 1317 & HSM $805 \mathrm{HD}$ & 467 & 25.3 & 30 & 47.64 & 1.82 \\
\hline 1324 & HSM 805HD & 1,193 & 37.8 & 30 & 33.19 & 1.66 \\
\hline $1338 b$ & HSM 805HD & 1,073 & 11.8 & 15 & 31.99 & 1.23 \\
\hline 1291 & HSM 805HD & 1,356 & 23.4 & 60 & 33.42 & 0.58 \\
\hline 1330 & HSM 805HD & 1,833 & 15.5 & 35 & 31.51 & 1.03 \\
\hline 1320 & HSM 805HD & 470 & 17.4 & 30 & 191.16 & 1.28 \\
\hline 1290 & HSM 805HD & 616 & 19.4 & 30 & 44.08 & 1.46 \\
\hline 721 & LKT 81 ITL (HC) & 316 & 21.3 & 18 & 40.11 & 1.82 \\
\hline $851 \mathrm{c}$ & LKT 81 ITL (HC) & 618 & 18.1 & 20 & 39.09 & 0.43 \\
\hline 745 & LKT 81 ITL (HC) & 526 & 20.5 & 35 & 151.79 & 2.72 \\
\hline 581 & LKT 81 ITL (HC) & 619 & 16.1 & 25 & 163.23 & 0.90 \\
\hline 1091 & LKT $81 \mathrm{~T}$ & 150 & 6.5 & 35 & 19.97 & 1.48 \\
\hline 1093 & LKT $81 T$ & 300 & 11.3 & 35 & 54.50 & 1.99 \\
\hline 234 & LKT 81T & 1,059 & 12.3 & 40 & 78.09 & 1.01 \\
\hline $1094 a$ & LKT 81T & 178 & 9.2 & 35 & 31.91 & 1.03 \\
\hline 253 & LKT 81 ITL & 1,112 & 17.4 & 40 & 291.50 & 1.89 \\
\hline $727 a$ & EQUUS $175 \mathrm{~N}$ & 541 & 18.3 & 40 & 359.50 & 2.00 \\
\hline
\end{tabular}

Table 2. Specifications of the skidders.

\begin{tabular}{|c|c|c|c|c|c|}
\hline \multirow{2}{*}{ Parameter } & \multicolumn{5}{|c|}{ Type of skidder } \\
\hline & HSM 805HD & EQUUS 175N & LKT $81 \mathrm{~T}$ & LKT 81 ITL (HC) & LKT 81 ITL \\
\hline Engine power $[\mathrm{kW}]$ & 129 & 125 & 74 & 85 & 85 \\
\hline Age of skidder in years & 12 & 1 & 24 & 1 & 3 \\
\hline Number of working day snapshot & 15 & 9 & 6 & 16 & 7 \\
\hline Number of runs & 77 & 34 & 34 & 55 & 31 \\
\hline Composition of the working group & $1+2$ & $1+1$ & $1+2$ & $1+2$ & $1+1$ \\
\hline Total skidded volume $\left[\mathrm{m}^{3}\right]$ & 527.6 & 359.5 & 184.5 & 394.2 & 310.1 \\
\hline Number of skidding stems [pcs] & 431 & 199 & 172 & 428 & 185 \\
\hline Equipment of skidder & $\mathrm{HC}, \mathrm{RC}, \mathrm{D}$ & $\mathrm{HC}, \mathrm{RC}, \mathrm{D}, \mathrm{C}$ & $\mathrm{D}$ & $\mathrm{HC}, \mathrm{RC}, \mathrm{D}, \mathrm{C}$ & $\mathrm{RC}, \mathrm{D}$ \\
\hline
\end{tabular}

HC- hydraulic crane, RC - radio control, C - clam bunk, D - double drum winch.

skidder winch drum (cable skidders); in the case of chokerless stem skidding the operation begins with the skidder movement towards the skidding line and finishes when the log reaches the skidding line.

- Skidder travel to other logs: this workoperation phase was registered with skidders that carried out cablegrapple log skidding. The phase begins by placing the skidded log on the skidding line and continues with the subsequent movement of the tractor to other cut stems. The phase is terminated when the skidder reaches another cut stem.

- Load skidding: the operation starts with skidding the load from the skidding line to the forest landing and finishes when the skidder stops at the forest landing.

- Load unhooking: the operation starts by releasing the cable from the tractor winch drum and finishes by unfastening the load and winding up the cable on the skidder winch drum.

- Handling by the skidder operator: this work operation starts being registered as soon as the skidder operator begins carrying out grading the logs, and it is terminated by cutting all logs into selected assortments.

- Log piling: this work phase begins after finishing the previous phase and terminates after the last log is piled on the assortment piling.

\subsection{Data collection}

Measuring the time consumption of skidders was carried out using the methods of continual time study, i.e. by connecting the work day snapshot with the fluent chronometry. The work day snapshots were used to record the occurrence of unit, batch and shift times during work shift, e.g. time necessary for preparation and termination of work, biological and recreation break etc. Operative time of the skidder operator and two further categories of time losses, i.e. technical-organisation and personal losses were recorded, as well. All unit, batch and shift times of skidder operators including time losses were recorded throughout the entire shift.

Dividing the times of the skidder operator shift was carried out according to a verified Central European methodology published by the authors (Klouda et al. 1988; Lhotský 2005; Dvořák et al. 2010).

During measuring the time consumption of skidder operator shift, the timekeeper did not interrupt the work process with work orders and recommended technological procedures, which could affect the regular condition of the production process. Nevertheless, the skidder operators were informed that measuring the time consumption of the shift was being carried out. Mostly operators who were expected to follow all work and safety regulations were selected for the study. 
The partial phases of work operation of the skidders (collecting time, load skidding etc.) were measured using the fluent chronometry with accuracy to seconds, and subsequently they were transcribed to electronic form for keeping the legibility and transparency.

Besides measuring the time consumption of partial work operations, the study was focused also on factors which affected significantly the time consumption of this technology. Following the results of studies from abroad (Howard 1987; Kluender et al. 1997; Behjou et al. 2008; Borz et al. 2013; Proto et al. 2018), following production factors were selected: the skidding distance, the number of logs in a load, wood species, winching distance, mean tree volume of skidded logs and work cycle load volume.

These factors were measured throughout all skidder work cycles. The skidding distance and winching distance were measured using a digital laser range finder TruPulse 360B or using a GPS receiver. Mean diameter and length of the skidded logs were measured using forestry callipers and tape measure, and subsequently the load volume in individual skidder work cycles was calculated using log volume tables. The number of logs in a load and wood species were recorded visually. Professional digital stopwatch Fastime 26 was used to record the time of partial work operations. Prior to statistical evaluation of measuring the time consumption, the time series was processed and unreliable and erroneous measurements were excluded from the time series. The recorded data were subsequently processed using the methods of generalized linear model (GLM). The statistical analysis was performed in the software STATISTICA 12.0 (StatSoft 2012) and using the programming language $R$.

\section{Results}

Table 3 presents the mean time consumption of individual monitored phases of a shift of monitored skidder operators, as well as the mean time of the shift. The data indicate that the operative time is $75.6 \%$ on average, and the remaining $24.4 \%$ covers non-operation time of the shift (technical service of the workplace, biological and recreational breaks etc.). The highest average percentage of non-operation time was recorded with the technical service of the workplace $8.5 \%$, whereas the lowest average percentage is represented by work orders $1.4 \%$. Technical and organisational time losses caused mainly by skidder operators waiting until the loggers finish their work (delimbing etc.) cover $2.83 \%$ of the shift on average. Personal losses represent only $5 \%$ of the whole time loses and were caused mainly by personal telephone calls of the skidder operators and talks with other technical staff on extracurricular topics. The average shift length of monitored skidder operators in this study represents 451.2 minutes $(7.52 \mathrm{~h})$, being 29 minutes less than the length of a standard shift $(8 \mathrm{~h})$. Regarding the average time for biological and recreational breaks during a shift (Table 3), none of the monitored skidder operators met the legally determined length of break for rest and refreshment, which according to $\$ 91$ of the Labour Code is at least 30 minutes for work longer than 6 hours.

Table 4 presents the percentage of individual partial operations of cable and cable-grapple skidders. The data show that the highest ratio of the overall work cycle of cable-grapple skidders is represented by log piling with the average of $28 \%$, followed by winching the load (15.3\%) and load skidding (13.3\%). When analysing the work operations of the operators of cable skidders, $22.5 \%$ of the time was taken by two operations - load skidding and handling by the skidder operator, followed by unloaded travel (17\%) and load collecting (11.5\%). When comparing the percentage of work operations carried out by cable skidder operators (Table 4 ), it is obvious that the most significant differences were recorded with unhooking the load and log piling, which can be associated with more modern equipment of the LKT 81 ITL skidder compared to LKT 81T and with the skills and experience of the operator. In addition, it can result from significantly different representation of work operations caused by different average skidding distance (Table 5) recorded with these skidders. In the case of cable-grapple skidders, more significant differences in the ratio of handling by the skidder operators of individual skidder types (EQUUS $175 \mathrm{~N}$ versus HSM $805 \mathrm{HD}$ and LKT 81 ITL (HC)) were recorded. The higher percentage of this operation in the case of EQUUS $175 \mathrm{~N}$ skidder is caused by the division of work within the working group, where a part of the handling process (measuring off) was carried out solely by the skidder operator without the assistance of the logger.

The average time consumption for partial work operations, as well as corresponding average values of production factors of the skidders are illustrated in Table

Table 3. The balance of the average consumption of shift time of skidder operators (Dvořák et al. 2011).

\begin{tabular}{|c|c|c|c|c|c|}
\hline \multirow{2}{*}{ Work shift components } & HSM 805 HD & EQUUS 175N & LKT 81T & LKT 81 ITL $(\mathrm{HC})$ & LKT 81 ITL \\
\hline & \multicolumn{5}{|c|}{ [min.] } \\
\hline$\overline{\text { Work operation }\left(\mathrm{T}_{\mathrm{A} 1}\right)}$ & 338 & 337 & 303.5 & 350 & 376 \\
\hline Preparation and termination of work $\left(\mathrm{T}_{\mathrm{B} 101}\right)$ & 8 & 18 & 18 & 12 & 16 \\
\hline Work orders $\left(\mathrm{T}_{\mathrm{B} 102}\right)$ & 4 & 7 & 8 & 7 & 3.7 \\
\hline Technical service of the workplace $\left(\mathrm{T}_{\mathrm{C} 103}\right)$ & 54 & 15 & 78 & 41 & 3.2 \\
\hline Technical service of the machine $\left(\mathrm{T}_{\mathrm{c} 104}\right)$ & 13 & 10 & 8 & 7.6 & 9 \\
\hline Machine defaults repair $\left(\mathrm{T}_{\mathrm{c} 105}\right)$ & 17 & 25.5 & 20 & 1.4 & 1.7 \\
\hline Biological and recreational breaks $\left(\mathrm{T}_{2}\right)$ & 20.5 & 23 & 7.5 & 20 & 7 \\
\hline Technical-organizational losses $\left(\mathrm{T}_{\mathrm{E}}\right)$ & 3 & 25 & 8 & 9 & 19 \\
\hline Personal losses $\left(T_{D}\right)$ & 0.5 & 0.5 & 1 & 1 & 0.4 \\
\hline Average working time $(\mathrm{T})$ & 458 & 461 & 452 & 449 & 436 \\
\hline
\end{tabular}


Table 4. Time consumption distribution of cable and cablegrapple skidders.

\begin{tabular}{|c|c|c|c|c|c|}
\hline \multirow{3}{*}{ Work phase } & \multicolumn{3}{|c|}{ Cable-grapple skidder } & \multicolumn{2}{|c|}{ Cable skidder } \\
\hline & $\sum_{\substack{\infty \\
\infty}}^{\infty}$ & 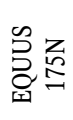 & 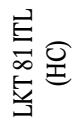 & $\begin{array}{l}E \\
E \\
E \\
\end{array}$ & $\stackrel{\infty}{\vec{b}}$ \\
\hline & \multicolumn{5}{|c|}{$[\%]$} \\
\hline Travel unloaded & 13 & 11 & 9 & 16 & 18 \\
\hline Cable releasing & 0 & 2 & 1 & 4 & 3 \\
\hline Collecting time & 10 & 13 & 14 & 10 & 13 \\
\hline Winching load & 16 & 11 & 19 & 7 & 6 \\
\hline Travel skidder to other logs & 5 & 7 & 9 & 1 & 1 \\
\hline Skidding load & 14 & 15 & 12 & 18 & 27 \\
\hline Unhooking load & 6 & 4 & 8 & 8 & 3 \\
\hline Handling by the skidder operator & 3 & 11 & 3 & 23 & 22 \\
\hline Log piling & 33 & 26 & 25 & 13 & 7 \\
\hline
\end{tabular}

Table 5. Average time consumption of elements work operation of monitored skidders.

\begin{tabular}{|c|c|c|c|c|c|}
\hline \multirow{3}{*}{ Elements of work operation } & \multicolumn{5}{|c|}{ Type of skidder } \\
\hline & 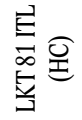 & 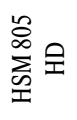 & 总忌 & $\begin{array}{l}E \\
\infty \\
5 \\
\bar{J}\end{array}$ & $\begin{array}{l}\vec{E} \\
\overrightarrow{\bar{D}} \\
\underline{\underline{J}}\end{array}$ \\
\hline & \multicolumn{5}{|c|}{ [min.] } \\
\hline Travel unloaded & 6.68 & 6.99 & 7.75 & 8.24 & 12.90 \\
\hline Cable releasing & 0.38 & 0.09 & 1.51 & 1.61 & 2.13 \\
\hline Collecting time & 10.56 & 5.14 & 9.04 & 4.72 & 8.85 \\
\hline Winching load & 13.85 & 9.04 & 8.06 & 3.17 & 4.14 \\
\hline Travel skidder to other logs & 6.52 & 2.79 & 4.96 & 0.25 & 0.51 \\
\hline Skidding load & 9.12 & 7.55 & 9.83 & 9.65 & 19.78 \\
\hline Unhooking load & 6.00 & 3.17 & 3.05 & 3.75 & 2.32 \\
\hline $\begin{array}{l}\text { Handling by the skidder } \\
\text { operator }\end{array}$ & 3.41 & 1.72 & 8.05 & 9.25 & 15.85 \\
\hline Log piling & 19.42 & 18.32 & 17.66 & 5.06 & 5.25 \\
\hline Total cycle time & 74.71 & 54.81 & 70.16 & 45.70 & 69.63 \\
\hline \multicolumn{6}{|c|}{ Factors of production } \\
\hline Number of logs in a load [pcs] & 7.98 & 5.59 & 6.00 & 5.06 & 5.68 \\
\hline Load volume $\left[\mathrm{m}^{3}\right]$ & 7.95 & 6.96 & 11.27 & 5.43 & 9.40 \\
\hline Mean tree volume $\left[\mathrm{m}^{3}\right]$ & 1.41 & 1.45 & 1.99 & 1.38 & 1.79 \\
\hline Skidding distance $[\mathrm{m}]$ & 533.68 & 699.46 & 530.00 & 545.85 & $1,111.51$ \\
\hline Winching distance $[\mathrm{m}]$ & 17.34 & 17.65 & 18.56 & 11.08 & 15.15 \\
\hline
\end{tabular}

5. The data show that the biggest differences in the time consumption between the cable and cable-grapple skidder operators were recorded in the case of the following operations: releasing the cable into the stand, winching the load, skidder travel to other logs, log piling and handling by the skidder operator. When comparing the average time consumption required for piling the logs, it can be seen that the cable-grapple skidder operators needed 3.5 times more time for this operation than cable skidder operators. This significant difference can be explained by different procedure of carrying out the operation (hydraulic crane versus stacking blade). Differences in time consumption of further two operations, cable releasing and skidder travel to other logs, between the two types of skidders were associated with the working method of the operators of cable skidder (using a cable winch) and cable-grapple skidders (using a hydraulic crane), as well as with applying cable and cable-grapple skidding method. The results of comparing the average time consumption of winching the load of the two types of tractors (Table 5) indicate that cable-grapple skidder operators needed on average 2.8 times more time than the operators of cable skidders. This fact is probably caused by the different method of carrying out the operation (winch versus hydraulic crane), as well as by longer average winching distance by $4.75 \mathrm{~m}$ in the case of cable-grapple skidders. The average time consumption of the operation - handling by the skidder operators is by $48 \%$ higher in the case of the cable skidders. This difference is caused by the fact that the operators of cable skidders carried out log measuring and log sawing all by themselves, without any assistance of loggers, while in the case of cable-grapple operators, these activities were carried out with the assistance of loggers from the working groups. Regarding the average number of logs in one load, the cable-grapple skidder operators compiled the load from a higher number of logs (6.52 pcs) compared to the operators of cable skidders (5.37 pcs), what eventually affected also the final mean volume of the load. The mean load volume of cable-grapple skidder operators was

Table 6. Mean nett and gross production rate and average driving speeds of skidders.

\begin{tabular}{|c|c|c|c|c|c|c|c|c|}
\hline \multirow[t]{2}{*}{ S } & \multirow[t]{2}{*}{ Type of skidder } & \multirow{2}{*}{$\begin{array}{l}\text { Skidding distance } \\
{[\mathrm{m}]}\end{array}$} & \multirow{2}{*}{$\begin{array}{l}\text { Load volume } \\
\qquad\left[\mathrm{m}^{3}\right]\end{array}$} & $\begin{array}{c}\text { Nett } \\
\text { production rate }\end{array}$ & $\begin{array}{c}\text { Normative work } \\
\text { performance }\end{array}$ & $\begin{array}{c}\text { Gros } \\
\text { production rate }\end{array}$ & Empty travel speed & Skidding speed \\
\hline & & & & \multicolumn{3}{|c|}{$\left[\mathrm{m}^{3} \mathrm{~h}^{-1}\right]$} & \multicolumn{2}{|c|}{$\left[\mathrm{km} \mathrm{h}^{-1}\right]$} \\
\hline 1320 & HSM 805HD & 470 & 6.94 & 7.23 & 5.16 & 5.13 & 3.87 & 4.51 \\
\hline 1318 & HSM 805HD & 424 & 8.91 & 9.04 & 6.74 & 6.74 & 2.73 & 3.81 \\
\hline 1322 & HSM 805HD & 87 & 3.02 & 4.69 & 3.42 & 3.33 & 4.67 & 5.27 \\
\hline 1315 & HSM 805HD & 1099 & 7.41 & 5.97 & 4.70 & 4.66 & 2.54 & 3.92 \\
\hline 1317 & HSM 805HD & 467 & 7.94 & 7.24 & 6.15 & 6.15 & 8.96 & 8.31 \\
\hline 1324 & HSM 805HD & 1192,5 & 8.30 & 8.62 & 4.29 & 4.28 & 7.84 & 5.62 \\
\hline $1338 b$ & HSM 805HD & 1073 & 6.40 & 6.19 & 4.16 & 4.16 & 8.40 & 5.87 \\
\hline 1291 & HSM 805HD & 1356 & 6.68 & 5.40 & 4.44 & 4.41 & 8.99 & 5.82 \\
\hline 1330 & HSM 805HD & 1833 & 7.88 & 5.04 & 4.28 & 4.28 & 5.65 & 5.41 \\
\hline 1290 & HSM 805HD & 616 & 8.63 & 8.88 & 7.02 & 6.91 & 6.47 & 4.73 \\
\hline 721 & LKT 81 ILT (HC) & 316 & 8.01 & 6.31 & 4.48 & 4.21 & 4.45 & 3.75 \\
\hline $851 \mathrm{c}$ & LKT 81 ILT (HC) & 618 & 5.58 & 4.36 & 3.64 & 3.58 & 4.29 & 4.29 \\
\hline 745 & LKT 81 ILT (HC) & 526 & 11.90 & 5.80 & 4.84 & 4.72 & 3.42 & 3.36 \\
\hline 581 & LKT 81 ILT (HC) & 619 & 6.63 & 4.38 & 3.60 & 3.51 & 6.35 & 3.43 \\
\hline 1091 & LKT $81 \mathrm{~T}$ & 150 & 3.33 & 8.53 & 6.25 & 5.97 & 3.26 & 3.75 \\
\hline 1093 & LKT $81 \mathrm{~T}$ & 300 & 5.45 & 7.66 & 4.07 & 3.91 & 4.00 & 4.05 \\
\hline $1094 a$ & LKT $81 \mathrm{~T}$ & 178 & 6.38 & 6.22 & 4.67 & 4.56 & 4.35 & 3.33 \\
\hline 234 & LKT $81 \mathrm{~T}$ & 1059 & 6.01 & 4.99 & 3.38 & 3.38 & 1.87 & 2.56 \\
\hline 253 & LKT 81 ITL & 1112 & 9.40 & 7.01 & 6.37 & 5.97 & 5.17 & 3.37 \\
\hline $727 \mathrm{a}$ & EQUUS 175N & 541 & 10.96 & 7.58 & 6.38 & 5.85 & 4.19 & 3.22 \\
\hline
\end{tabular}


$15 \%$ higher than the mean volume of the cable skidder operators.

Table 6 presents the mean nett production rate, normative work performance as well as the gross production rate of the skidder operators in individual forest stands. In addition, the table contains also the mean speed of the skidders with and without the load. The mean gross production rate of the monitored skidders varied between 3.33 and $6.91 \mathrm{~m}^{3} \mathrm{~h}^{-1}$ depending on the type of the forest stand and the skidding distance. When comparing the differences in the nett production rate and the gross production rate of the skidders (Table 6), it can be concluded that due to affecting the gross production rate by the amount of non-operation shift times, the gross production rate is $24.4 \%$ lower than the nett production rate, which covers the skidding efficiency recalculated to the nett time consumption of the skidder operators without the non-operation shift times. Normative work performance of the studied skidders covering the work performance without time losses ranged from 3.42 to $7.02 \mathrm{~m}^{3} \mathrm{~h}^{-1}$. When compared to the gross production rate, it represents an increase of $2.83 \%$ in work productivity.

The dependence of the gross production rate of the skidders on the skidding distance and the mean load volume is illustrated in Figure 3. The graph shows that the increasing skidding distance and the decreasing load volume causes a decrease in the gross production rate of the skidders.

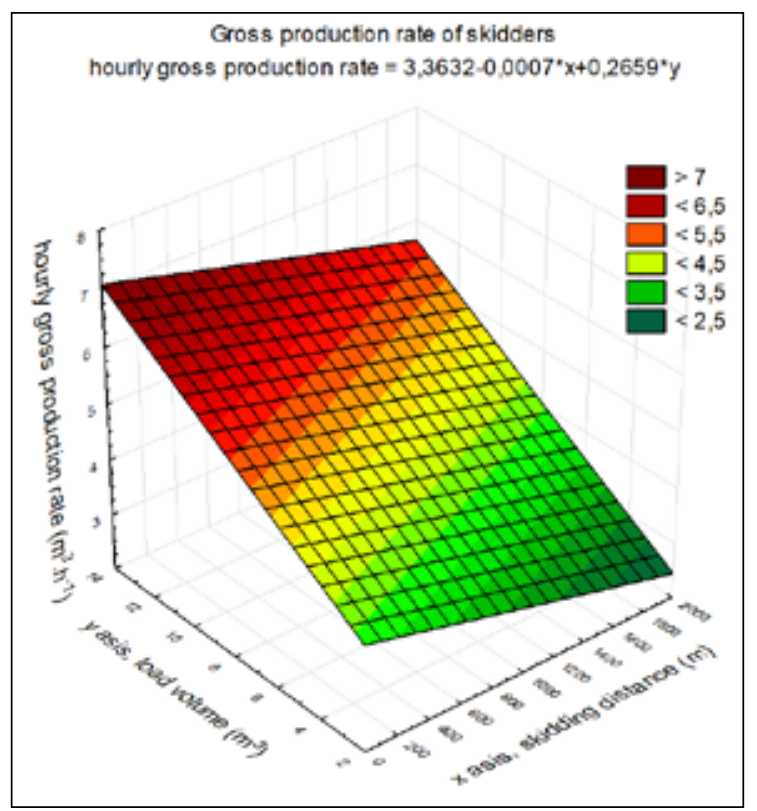

Fig. 3. Three-dimensional graphic illustration of gross production rate in relation to skidding distance and mean load volume.

Tables 7 and 8 illustrate the generalized linear models of time consumption calculated for almost all partial work operations of cable and cable grapple skidders.
After the gradual regression method based on AIC (Akaike Information Criterion) 7 models of partial work operations of cable skidders and 8 models of partial work operations of cable-grapple skidders including a model of overall time of work cycle were created. After comparing the models of time consumption for partial work operations of the two types of skidders (cable versus cable-grapple skidder), it can be concluded that the differences in the number and the type of affecting production factors were discovered in the following operations: load pilling, winching the load, unhooking the load and handling carried out by the skidder operator.

\section{Discussion}

Due to different conditions in the forest stands and terrain (forest stand composition, operation and terrain conditions) the results of the time study and the models are applicable only in the situations with the same or similar work conditions (Mousavi et al. 2012; Borz et al. 2015).

Non-operation shift times represent on average $24.4 \%(14-33 \%)$ of all monitored skidder operators. For illustration and comparison Borz et al. (2015) and Borz et al. (2014a) mention a higher percentage of non-operation times $29.3 \%$ and $28 \%$. Sabo \& Poršinsky (2005) in their study indicate $32.15 \%$ of non-operation time for the cable skidder Timberjack $240 \mathrm{C}$, which can be compared with the percentage of non-operation times of the LKT 81T operator in the present study (33\%). The highest amount of non-operation times -51 and $43 \%$ for cable skidders (TAF 690 OP, TAF 657) are mentioned by Borz et al. (2013), whereas the lowest amount of $14 \%$ was recorded in the study of Nikooy et al. (2013). This data are in accordance with the amount of non-operation times of the LKT 81 ITL operator monitored in the present study. The amount of non-operation shift times of the skidder operators monitored in this study is affected mostly by the amount of time consumed for the technical operation of the workplace, occurrence of repairs and machinery malfunctions during the sift, as well as by the technical and organisational time losses representing the highest ration of all time losses $-95 \%$. These time losses can be avoided by planning and organising the work better.

The model of the partial work operation - travel from the forest landing into the forest stand of both types of studied skidders depends on the skidding distance (Table 7 and 8). These results are in accordance with other studies (Wang et al. 2004; Nurminen et al. 2006; Mousavi et al. 2012; Mousavi et al. 2013; Marčeta et al. 2014). The operation of cable skidders - releasing the cable is affected only the winching distance, presented also in the following studies (Mousavi 2012a; Mousavi 2012b; Marčeta et al. 2014; Borz et al. 2014a). Generalized linear models for the time consumption of the operation - load winching of the cable skidder revealed that the 
Table 7. Generalized linear model of cable skidders.

\begin{tabular}{|c|c|c|c|c|c|c|c|c|c|}
\hline Elemental of working operation & $\mathrm{AIC}$ & Nul dev. & Residual dev. & Coefficient & Estimate & Standard Error & t-value & p-value & \\
\hline \multirow{3}{*}{ Travel unloaded } & \multirow{3}{*}{296.4} & \multirow{3}{*}{$1,593.3$} & \multirow{3}{*}{321.8} & Intercept & 1.831 & 0.623 & 2.94 & 0.005 & ** \\
\hline & & & & LKT 81 ITL & -1.793 & 0.752 & -2.39 & 0.020 & * \\
\hline & & & & xsd & 0.012 & 0.001 & 13.21 & 0.000 & *** \\
\hline \multirow{2}{*}{ Cable releasing } & \multirow{2}{*}{160.0} & \multirow{2}{*}{76.0} & \multirow{2}{*}{48.3} & Intercept & 0.300 & 0.321 & 0.94 & 0.353 & \\
\hline & & & & xwd & 0.115 & 0.020 & 5.67 & 0.000 & $* * *$ \\
\hline \multirow{3}{*}{ Collecting time } & \multirow{3}{*}{323.2} & \multirow{3}{*}{$1,187.1$} & \multirow{3}{*}{485.9} & Intercept & -0.268 & 0.861 & -0.31 & 0.757 & \\
\hline & & & & LKT 81 ITL & 3.541 & 0.707 & 5.01 & 0.000 & $* * *$ \\
\hline & & & & $\mathrm{xn}$ & 0.986 & 0.141 & 6.98 & 0.000 & $* * *$ \\
\hline \multirow{3}{*}{ Winching the load } & \multirow{3}{*}{243.4} & \multirow{3}{*}{241.8} & \multirow{3}{*}{177.5} & Intercept & 0.618 & 0.738 & 0.84 & 0.405 & \\
\hline & & & & xn & 0.266 & 0.095 & 2.80 & 0.007 & $* *$ \\
\hline & & & & xwd & 0.116 & 0.037 & 3.12 & 0.003 & $* *$ \\
\hline \multirow{4}{*}{ Skidding load } & \multirow{4}{*}{373.2} & \multirow{4}{*}{$4,862.9$} & \multirow{4}{*}{$1,016.6$} & Intercept & -5.368 & 1.870 & -2.87 & 0.006 & ** \\
\hline & & & & LKT 81 ITL & -4.449 & 1.835 & -2.43 & 0.018 & * \\
\hline & & & & xsd & 0.017 & 0.002 & 10.63 & 0.000 & $* * *$ \\
\hline & & & & $\mathrm{xvl}$ & 1.054 & 0.295 & 3.57 & 0.001 & $* * *$ \\
\hline \multirow{3}{*}{ Unhooking load } & \multirow{3}{*}{223.5} & \multirow{3}{*}{273.7} & \multirow{3}{*}{104.8} & Intercept & 0.738 & 0.399 & 1.85 & 0.069 & \\
\hline & & & & LKT 81 ITL & -1.892 & 0.328 & -5.76 & 0.000 & $* * *$ \\
\hline & & & & $\mathrm{xn}$ & 0.595 & 0.065 & 9.08 & 0.000 & $* * *$ \\
\hline \multirow{3}{*}{ Handling by the skidder operator } & \multirow{3}{*}{377.1} & \multirow{3}{*}{$2,234.0$} & \multirow{3}{*}{$1,398.4$} & Intercept & 1.872 & 2.011 & 0.93 & 0.356 & \\
\hline & & & & $\mathrm{xn}$ & 0.844 & 0.265 & 3.19 & 0.002 & $* *$ \\
\hline & & & & $\mathrm{xvl}$ & 0.891 & 0.221 & 4.02 & 0.000 & $* * *$ \\
\hline \multirow{5}{*}{ Total cycle time } & \multirow{5}{*}{457.4} & \multirow{5}{*}{$27,559.0$} & & Intercept & 0.090 & 5.179 & 0.02 & 0.986 & \\
\hline & & & & xsd & 0.026 & 0.004 & 5.98 & 0.000 & $* * *$ \\
\hline & & & $5,882.6$ & xwd & 0.426 & 0.249 & 1.71 & 0.092 & . \\
\hline & & & & $\mathrm{xn}$ & 2.868 & 0.649 & 4.42 & 0.000 & $* * *$ \\
\hline & & & & $\mathrm{xvl}$ & 2.033 & 0.686 & 2.96 & 0.004 & $* *$ \\
\hline
\end{tabular}

(xsd - skidding distance, xwd - winching distance, xvl - volume load, xn - number of logs in a load)

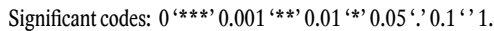

Table 8. Generalized linear model of cable-grapple skidders.

\begin{tabular}{|c|c|c|c|c|c|c|c|c|c|}
\hline Elemental of working operation & AIC & Nul dev. & Residual dev. & Coefficient & Estimate & Standard Error & t-value & $\mathrm{p}$-value & \\
\hline \multirow{3}{*}{ Travel unloaded } & \multirow{3}{*}{810.7} & \multirow{3}{*}{$2,016.3$} & \multirow{3}{*}{$1,223.5$} & Intercept & 3.789 & 0.429 & 8.84 & 0.000 & $* * *$ \\
\hline & & & & HSM & -0.988 & 0.438 & -2.26 & 0.025 & * \\
\hline & & & & xsd & 0.006 & 0.001 & 10.28 & 0.000 & *** \\
\hline \multirow{5}{*}{ Collecting time } & \multirow{5}{*}{891.8} & \multirow{5}{*}{$4,033.7$} & \multirow{5}{*}{$2,165.4$} & Intercept & 0.758 & 1.322 & 0.57 & 0.568 & \\
\hline & & & & HSM & -1.779 & 0.855 & -2.08 & 0.039 & * \\
\hline & & & & LKT 81 ITL & 1.679 & 0.882 & 1.90 & 0.059 & . \\
\hline & & & & xn & 0.586 & 0.084 & 7.10 & 0.000 & $* * *$ \\
\hline & & & & xvl & 0.419 & 0.099 & 4.23 & 0.000 & *** \\
\hline \multirow{4}{*}{ Winching the load } & \multirow{4}{*}{1062.6} & \multirow{4}{*}{$8,076.8$} & \multirow{4}{*}{$5,956.2$} & Intercept & 2.939 & 1.341 & 2.19 & 0.030 & * \\
\hline & & & & LKT 81 ITL & 3.546 & 1.076 & 3.29 & 0.001 & ** \\
\hline & & & & $\mathrm{xn}$ & 0.717 & 0.138 & 5.21 & 0.000 & $* * *$ \\
\hline & & & & xwd & 0.102 & 0.055 & 1.85 & 0.066 & \\
\hline \multirow{3}{*}{ Travel skidder to other logs } & \multirow{3}{*}{727.2} & \multirow{3}{*}{$2,461.3$} & \multirow{3}{*}{2,065} & Intercept & 4.048 & 0.892 & 4.54 & 0.000 & $* * *$ \\
\hline & & & & HSM & -2.065 & 0.744 & -2.78 & 0.006 & ** \\
\hline & & & & $\mathrm{xn}$ & 0.351 & 0.100 & 3.53 & 0.000 & $* * *$ \\
\hline \multirow{4}{*}{ Skidding load } & \multirow{4}{*}{802.9} & \multirow{4}{*}{$3,346.9$} & \multirow{4}{*}{$1,153.2$} & Intercept & 2.302 & 0.685 & 3.36 & 0.001 & $* * *$ \\
\hline & & & & HSM & -2.795 & 0.456 & $-6,13$ & 0.000 & $* * *$ \\
\hline & & & & xsd & 0.009 & 0.001 & 15.62 & 0.000 & $* * *$ \\
\hline & & & & $\mathrm{xvl}$ & 0.239 & 0.066 & 3.64 & 0.000 & $* * *$ \\
\hline \multirow{5}{*}{ Unhooking load } & \multirow{5}{*}{709,2} & \multirow{5}{*}{$1,204.0$} & \multirow{5}{*}{660.8} & Intercept & $-0,767$ & 0.705 & $-1,09$ & 0.278 & \\
\hline & & & & HSM & 1.053 & 0.468 & 2.25 & 0.026 & * \\
\hline & & & & LKT 81 ITL & 3.121 & 0.482 & 6.48 & 0.000 & $* * *$ \\
\hline & & & & xn & 0.265 & 0.046 & 5.82 & 0.000 & $* * *$ \\
\hline & & & & xvl & 0.200 & 0.053 & 3.79 & 0.000 & $* * *$ \\
\hline \multirow{3}{*}{ Handling by the skidder operator } & & & & Intercept & 0.600 & 1.628 & 0.37 & 0.713 & \\
\hline & 446.7 & $1,882.2$ & $1,265.4$ & HSM & $-2,064$ & 0.999 & $-2,07$ & 0.042 & * \\
\hline & & & & $\mathrm{xvl}$ & 0.738 & 0.152 & 4.84 & 0.000 & $* * *$ \\
\hline & & & & Intercept & $-1,623$ & 2.725 & $-0,60$ & 0.552 & \\
\hline & & & & HSM & 7.242 & 1.825 & 3.97 & 0.000 & $* * *$ \\
\hline Log piling & 1166.1 & $14,282.0$ & 10,162 & LKT 81 ITL & 5.789 & 1.880 & 3.80 & 0.002 & ** \\
\hline & & & & xn & 0.384 & 0.176 & 2.18 & 0.031 & * \\
\hline & & & & $\mathrm{xvl}$ & 1.510 & 0.204 & 7.39 & 0.000 & $* * *$ \\
\hline & & & & Intercept & 4.839 & 4.141 & 1.17 & 0.244 & \\
\hline & & & & LKT 81 ITL & 10.799 & 2.930 & 3.69 & 0.000 & $* * *$ \\
\hline Total cycle time & 1408.2 & 109,088 & 43,688 & xsd & 0.013 & 0.004 & 3.30 & 0.001 & ** \\
\hline & & & & $\mathrm{xn}$ & 2.793 & 0.393 & 7.11 & 0.000 & $* * *$ \\
\hline & & & & $\mathrm{xvl}$ & 3.687 & 0.381 & 9.69 & 0.000 & $* * *$ \\
\hline
\end{tabular}

(xsd - skidding distance, $x w d$ - winching distance, $x v l$ - volume load, $x n$ - number of logs in a load)

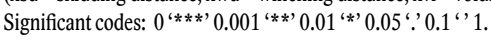


winching distance and the number of logs in the load affected significantly the time consumption of this work operation. Same results were confirmed also in further studies (Mousavi 2012b; Borz et al. 2013). The time consumption of load winching of the cable-grapple skidders is statistically significantly affected only by the number of logs in the load. The time consumption of collecting time in the case of cable-grapple skidders is statistically significantly affected by the volume and number of logs in the load. In the case cable skidder only the dependence on the number of logs was statistically significant, what is in accordance with the study of Mousavi (2012a). Najafi et al. (2007) conducted a time study focused on the skidder HSM-904, which found out that the skidding time depends on the skidding distance and the number of logs in the load. However, Lotfalian et al. (2011) established in their study that the skidding time depends on the skidding distance and the slope inclination. The present study established the skidding distance and load volume to be the statistically significant variables affecting the time consumption of load skidding for both, cable and cable-grapple skidders. These results are in accordance with the results presented in the study by Marčeta et al. (2014). After comparing the models of time consumption of unhooking the load with the two types of studied skidders, the study shows that the number of logs in the load and the load volume are statistically significant factors affecting the time consumption of this operation with the cable-grapple skidders. In the case of cable skidders only the number of logs in the load affects the time consumption of unhooking the load. Nevertheless, the time studies of Mousavi et al. (2013); Proto et al. (2018) did not prove any of the studied independent variables to be statistically relevant in regard to the time consumption of unhooking the load. Wang et al. (2004) found out that the time consumption of unhooking the load depends on the log diameter, mean merchantable height and the number of logs in the load. The overall time of the work cycle of the cable-grapple skidder operators is affected by the following factors: load volume, number of logs in the load and the skidding distance. Similar results were confirmed also in the study of Mousavi et al. (2012). However, different results are presented in the study of Mousavi et al. (2013) confirming the dependence of the overall time consumption of the HSM-904 skidder work cycle only on the number of logs and the load volume. Proto et al. (2018) confirmed the dependence of the overall work cycle time of the cable-grapple skidder John Deere $548 \mathrm{H}$ on the skidding distance and the load volume. The overall work cycle time of the studied cable skidders is affected mostly by the skidding distance, number of logs in the load, and the load volume was proven to have the least impact. The same results are presented in the study by Nikooy et al. (2013). However, different findings are presented by Ghaffariyan et al. (2013) indicating the dependence of the overall work cycle time on the skidding distance, winching distance, inclination of the skidding line and the load volume. Behjou et al. (2008) and Behjou (2010) confirmed in their research studies the dependence of the overall work cycle time of skidder Timberjack 450C on the skidding distance, winching distance and interaction between the skidding distance and skidding line inclination. Borz et al. (2013) concluded in their study that the overall work cycle time of the cable skidder (TAF 690 OP, TAF 657) depends on the skidding distance and the winching distance, and in the case of skidder TAF 657 the number of logs was also another statistically significant factor. The partial work operation - log piling performed by the cable-grapple skidder is statistically significantly influenced by the load volume and number of logs in the load. This finding is in accordance with the results presented in the study of Mousavi et al. (2012). In the case of the same operation performed by the cable skidder no dependence on any of the studied factors was confirmed. Regarding the proportion, this work operation represents $10 \%$ on average of the shift of the cable skidders. These results can be compared to the results of study by Mousavi et al. (2012). The work operation - handling by the skidder operator is statistically significantly affected by the number of logs in the load and the load volume in the case of cable skidders, whereas in the case of cable-grapple skidders only the load volume was determined as the statistically significant factor.

Some of the conducted time studies revealed that the slope inclination can significantly affect the time consumption of the load winching and the travel from the forest landing into the forest stand. It can also influence the time distribution of partial work operation within a shift (Behjou et al. 2008; Mousavi 2009; Lotfalian et al. 2011; Mousavi 2012a; Magagnotti \& Spinelli 2012; Borz et al. 2014b). In the present study the slope inclination was not proven as a statistically significant factor affecting the time consumption of partial work operation - winching the load and travel from the forest landing into the forest stand, although the impact of this factor on the time consumption of the two above mentioned operations cannot be excluded.

In the forest stand conditions of the present study and with the studied skidders the time consumption of the load skidding was higher on average (Table 5) than the time consumption of the travel from the forest landing into the stand. This was reflected in the mean speed of the tractor travel from the forest landing into the stand, which ranged from $3.97 \mathrm{~km} \mathrm{~h}^{-1}$ to $6 \mathrm{~km} \mathrm{~h}^{-1}$. On the other hand, the mean load skidding speed was lower by $21 \%$ ranging from $3.23 \mathrm{~km} \mathrm{~h}^{-1}$ to $5.56 \mathrm{~km} \mathrm{~h}^{-1}$. In other studies the recorded mean speed of travel from the forest landing into the forest stand ranged from $4.15 \mathrm{~km} \mathrm{~h}^{-1}$ (Behjou et al. 2008) to $8.58 \mathrm{~km} \mathrm{~h}^{-1}$ (Proto et al. 2018), while the recorded mean skidding speed varied from $1.33 \mathrm{~km} \mathrm{~h}^{-1}$ (Zečić et al. 2005) to $7.31 \mathrm{~km} \mathrm{~h}^{-1}$ (Spineli \& Magagnotti 2012). The speed of skidder travel from the forest landing into the stand can be higher or lower than 
the skidding speed depending on various work conditions. For illustration, the time study of Borz et al (2013) can be mentioned, since this study confirmed a higher mean speed of a loaded skidder than the mean speed of unloaded skidder. Also in the present time study a higher mean speed of a loaded skidder travel was recorded in the subcompartments $(1315,1318,1320,1322,1091$ and 1093) than the travel speed of unloaded skidder. This fact is probably associated with the terrain character, soil humidity of the skidding road, as well as with a lower volume of skidded load from the given stands in the case of LKT 81T skidder. The highest mean speed of the skidder travel loaded $\left(5.56 \mathrm{~km} \mathrm{~h}^{-1}\right)$ and unloaded $\left(6 \mathrm{~km} \mathrm{~h}^{-1}\right)$ was recorded in the case of HSM 805HD skidder operator. These values are comparable with the results presented in the study by Mousavi et al. (2013), where the mean speed of loaded skidder HSM 904 was $5.17 \mathrm{~km} \mathrm{~h}^{-1}$ and the mean speed of unloaded skidder was $5.96 \mathrm{~km} \mathrm{~h}^{-1}$. When comparing the mean speed of the travel of the skidder LKT 81 ITL, the results show that both skidders achieve almost the same travel speeds whether loaded or unloaded. The differences do not exceed $0.39 \mathrm{~km} \mathrm{~h}^{-1}$ when unloaded and $0.15 \mathrm{~km} \mathrm{~h}^{-1}$ when loaded, what indicates that the differences in speed are probably caused by the differences in the terrain of skidding road and by accidental circumstances. The lowest mean travel speed of skidder from the forest landing into the forest stand of the studied skidders was recorded in the case of LKT 81T skidder tractor operator $\left(3.97 \mathrm{~km} \mathrm{~h}^{-1}\right)$. This can be associated with the lowest engine performance (Table 1) when compared with other studied skidders. The lowest mean skidding speed was recorded with the EQUUS $175 \mathrm{~N}$ skidder operator $\left(3.23 \mathrm{~km} \mathrm{~h}^{-1}\right)$. This is probably associated with the highest mean load volume $11.27 \mathrm{~m}^{3}$ (Table 5) from among all the studied skidder operators.

The mean gross production of cable skidders considering the type of the forest stand, mean skidding distance and the type of the skidder, ranged from $3.38 \mathrm{~m}^{3} \mathrm{~h}^{-1}$ to $5.97 \mathrm{~m}^{3} \mathrm{~h}^{-1}$, and in the case of cable-grapple skidders a comparable mean gross production ranging from $3.33 \mathrm{~m}^{3} \mathrm{~h}^{-1}$ to $6.91 \mathrm{~m}^{3} \mathrm{~h}^{-1}$ was recorded. Most of the studies from abroad mention higher gross production of cable-grapple skidders ranging from $6.1 \mathrm{~m}^{3} \mathrm{~h}^{-1}$ (Mousavi et al. 2012) to $32.8 \mathrm{~m}^{3} \mathrm{~h}^{-1}$ (Zečić et al. 2010). Porter \& Strawa (2006) in their study established a mean gross production of the skidder LKT $81 \mathrm{~T}$ of $7.15 \mathrm{~m}^{3} \mathrm{~h}^{-1}$ in an 82-year-old fir stand. By comparison, the present study recorded lower gross production of the skidder LKT 81T of only $5.97 \mathrm{~m}^{3} \mathrm{~h}^{-1}$ with the mean skidding distance of $150 \mathrm{~m}$. When compared to the time study by Borz et al. (2013) the gross production of the cable skidders of the TAF type is 3.20 and $3.75 \mathrm{~m}^{3} \mathrm{~h}^{-1}$ with the mean skidding distance ( 980 and $871 \mathrm{~m}$ ), which is comparable with the production of $3.38 \mathrm{~m}^{3} \mathrm{~h}^{-1}$ of the LKT 81T skidder with the comparable skidding distance $(1,059 \mathrm{~m})$ presented in this study. The gross production rate of the studied skid- ders was affected strongly by the ratio of non-operation times within the shift (24.4\%) as well as by the mean skidding distance and mean load volume. These results are in accordance with the findings presented in the studies by Fiedler et al. (2008); Lopes et al. (2017), who concluded that the skidding distance and load volume affect the production of skidders to the greatest extent.

\section{Conclusion}

The submitted paper discussed the time study carried out for cable and cable-grapple skidders employed in the University Forestry Enterprise of the Technical University in Zvolen. One of the tasks of this study was to provide data regarding the work time consumption of the skidder operators and production and efficiency data of individual skidders. The relation between the time consumption of individual partial work operations of cable and cable-grapple skidders and independent variables was generalized in linear models. The generalized linear models indicated that the overall work cycle time of the cable and cable-grapple skidders depends on the skidding distance, load volume and number of logs in the load. The study results revealed noticeable differences in the time consumption and differences in the impact of production factors on individual partial work operation of the two types of skidders. Time losses of the skidder operators represent mean percentage of $2.98 \%$ from the overall shift time. This can be decreased by improving the planning and organisation of work. The results of this study can be used to determine the objective costs, work rationalisation, work planning and estimate of the time consumption. In addition, they can be used as background for objective evaluation of wages in the logging operations, since the time consumption analysis has to evaluate objectively the costs for timber skidding using skidder technology in various production and technical conditions while meeting the principles of economic efficiency, work humanisation as well as environmental requirements of forest ecosystems.

\section{References}

Abeli, W. S., 1996: Comparing productivity and cost of three sub grading machines. Journal Forest Enginerig, 51:33-39.

Acuma, M., Bigot, M., Guerra, S., Hartsough, B., Kanzian, C., Kärhä, K. et al. 2012: Good practice guidelines for biomass production studies. In: Magagnotti, N., Spinelli, R.: CNR IVALSA, Sesto Fiorentino, 51 p. Bavaghar, M. P., Sobhani, H., Feghhi, J., Darvishsefat, A. A., Marvi Mohajer, M. R., 2010: Comprehensive productivity models fot tracked and wheeled skidders in the Hyrcanian Forests of Iran. Research Journal of Forestry, 4:65-71. 
Behjou, F. K., Majnounian, B., Namiranian, M., Dvořák, J., 2008: Time study and skidding capacity of wheeled skidder Timberjack 450C in Caspian forests. Journal of Forest Science, 54:183-188.

Behjou, F. K., 2010: A techno-economic evaluation of skidding operation by Timberjack $450 \mathrm{C}$ and Clark Ranger 666DBS in Caspian forests. Journal of Food, Agriculture and Environmet, 8:1020-1023.

Björheden, R., 1991: Basic time cencepts for international comparisons of time study reports. Journal of Forest Engineering, 2:33-39.

Björheden, R., Apel, K., Shiba, M., Thompson, M., 1995: IUFRO forest work study nomenclature. Swedish Univerzity of Agricultural Science, Department of Operational Efficiency, Grapenberg, 16 p.

Borz, S. A., Dlnulca, F., Birda, M., Ignea, Ch., Clobanu, V.D., Popa, B., 2013:Time consumption and productivity of skidding Silver fir (Abies alba Mill.) round wood in reduced accessibility conditions: A case study in windthrow salvage logging from Romanian Carpathians. Annals of Forest Research, 56:363-375.

Borz, S. A., Ignea, G., Popa, B., 2014a: Assessing timber skidding efficiency in a group shelterwood system applied to a fir-beech stand. African Journal of Agricultural Research, 9:160-167.

Borz, S. A., Ignea, G., Popa, B., 2014b: Modeling and comparing timber winching performance in windthrow and uniform selective cuttings for two Romanian skidders. Journal of Forest Research 19:473-482.

Borz, S. A., Ignae, G., Popa, B., Spârchez, G., Iordache, E., 2015: Estimating time consumption and productivity of roundwood skidding in group shelterwood system - a Case study in a broadleaved mixed stand located in reduced accessibility conditions. Croation Journal of Forest Enginering, 36:137-146.

Dvořák, J., Gross, J., Oliva, J., Hošková, P., Malkovský, Z., 2010: Sestavení výkonových norem pro harvestory a vyvážecí traktory podle vykonových třid stroju a výrobních podmínek. Záverečná správa. Praha, ČZU v Praze, 79 p.

Dvořák, J., Bystrický, R., Hošková, P., Hrib, M., Jarkovská, M., Kováč, J. et al., 2011: The use of harvester technology in production forests. Kostelec nad Černými lesy, Lesnícka práce, 156 p.

Fiedler, N. C., Rocha, E. B., Lopes, E. S., 2008: Análise da produtividade de um sistema de colheita de árvores inteiras no norte do Estado de Goiás. Floresta, Curtiba, 38:577-586.

Ghaffariyan, M. R., Naghdi, R., Ghajar, I., Nikooy, M., 2013: Time prediction models and cost evaluation of cut-to-lenght (CTL) harvesting method in a mountainous forest. Small-scale Forest, 12:181-192.

Howard, A.F., 1987: Modeling the cost and profitability of timber harvesting with cable skidders. Northern Journal of Applied Forestry, 4:87-92.
Klouda, M., Syrovátka, K., Blud'ovský, Z., 1988: Normování práce vlesním hospodářství. Praha: Ministerstvo lesního a vodniho hospodařstvi a drevospracujúciho prumyslu ČSR, SZN v Praze, 207 p.

Kluender, R., Loretz, D., Mscoy, W., Stokes, B.J., Klepac, J., 1997: Productivity of rubber-tired skidders in southern pine forests. Journal of Forest Products, 47:53-58.

Kulak, D., Stańczykiewicz, A., Szewczyk, G., Kobiałka, P., 2013: Soil disturbances as result of timber skidding in fir-beech mountain stands. Forestry Letters, 105:35-46.

Kulak, D., Stańczykiewicz, A., Szewczyk, G., 2017: Productivity and time consumption of timber extraction with a grapple skidder in selected pine stands. Croatian Journal of Forest Engineering, 38:55-63.

Kulak, D., Stańczykiewicz, A., Szewczyk, G., Wala, Ł., 2019: Wydajność zrywki drewna skiderem na terenach pochyłych. Sylwan, 163:601-609.

Lhotský, O., 2005: Organizace a normování práce v podniku. Praha, ASPI, 100 p.

Lopes, E. S., Oliveira, D., Rodrigues, C. K., Drinko, C. H., 2017:Variables influencing working time and skidder productivity in wood extraction. Nativa: Pesquisas Agrárias e Ambientais, 5:298-302.

Lotfalian, M., Moafi, M., Foumani, B. S., Akbari, R. A., 2011:Time study and skidding capacity of the wheeled skidder Timberjack 450C. Journal of Soil Science and Environmental Management, 2:120-124.

Magagnotti, N., Spinelli, R., 2012: Replacing steel cable with synthetic rope to reduce operator workload during log winching operations. Small-scale Forestry, 11:223-236.

Marčeta, D., Petković, V., Košir, B., 2014: Comparison of Two Skidding Methods in Beech Forests in Mountainous Conditions. Nova mehanizacja šumarstva: Časopis za teoriji i praksu Šumarskoga inženjerstva, 35:51-62.

Mederski, P. S., Bembenek, M., Jörn, E., Dieter, D. F., Karasewski, Z., 2010: The enhancement of skidding produktivity resulting from changes in construction: grapple skidder vs. rope skidder. In: Proceedings of FORMEC 2010, Forest Engineering: Meeting the Needs of the Society and the Environment, Padova, 11.-14. July 2010, Padova, Formec, p. 1-7.

Mousavi, R., 2009: Comparison of productivity, cost and enviromental impacts of two harvesting methods in Northern Iran: short-log vs. long-log [Ph. D. Thesis.] Joensuu, Univerzity of Joensuu, 93 p.

Mousavi, R., 2012a: Time consumption, productivity, and cost analysis of skidding in the Hyrcanian forest in Iran. Journal of Forestry Research, 23:691-697.

Mousavi, R., 2012b: Effect of log length on productivity and cost of Timberjack 450C skidder in the Hyrcanian forest in Iran. Journal of Forest Science, 58:473-482. 
Mousavi, R., Nikooy, M., Nezhad, A. E., Ershadfar, M., 2012: Evaluation of full tree skidding by HSM-904 skidder in patch cutting of aspen plantation in Northern Iran. Journal of Forest Science, 58:79-87.

Mousavi, R., Nikooy, M., Naghdi, R., 2013: Comparison of timber using two ground-based skidding systems: grapple skidding vs. cable skidding. International Journal of Forest, Soil and Erosion, 3:79-86.

Naghdi, R., Nikoye Seyahkal, M., Bagheri, I., Javadpour, J., 2008: Comparison of production rate of skidder Timberjack 450C at two planned and unplanned logging condition. Iranian Journal of Forest and Poplar Research, 16:649-659.

Najafi, A., Sobhani, H., Seed, A., Makhdom, M., Marvi Mohajer, M. R., 2007: Time study of skidder HSM 904. Journal Iran. National Research, 60:921-930.

Nikooy, M., Esmailnezhad, A., Naghdi, R., 2013: Productivity and cost analysis of skidding with Timberjack 450C in forest plantations in Shafaround watershed, Iran. Journal of Forest Science, 59:261-266.

Nurminen, T., Korúunen, H., Uusitalo, J., 2006: Time consumption analysis of the mechanized cut-to lenght harvesting system. Silva Fenica, 40:335-363.

Porter, B., Strawa, P., 2006: Analiza pozyskiwania i zrywki drewna w drzewostanach Jodłowych. Sylwan, 1:67-72.

Proto, A. R., Macrí, G., Visser, R., Russo, D., Zimbalatti, G., 2018: Comparison of timber extraction productivity between winch and grapple skidding: A case study in Southern Italian Forests. Forests, 9:1-12.
Sabo, A., Poršinsky, T., 2005: Skidding of fir roundwood by Timberjack $240 \mathrm{C}$ from selective forests of Gorski Kotar. Croatian Journal of Forest Engineering, 26:13-27.

Sarikhani, N., 2001: Forest utilization. Tehran Univerzity, Tehran, $728 \mathrm{p}$.

Spinelli, R., Magagnotti, N., 2012: Wood extraction with farm tractor and sulky: Estimating productivity, cost and energy consumption. Small-scale Forestry, 11:73-85.

Wang, J., Long, C., McNeel, J., Baumgras, J., 2004: Productivity and cost of manual felling and cable skidding in central Appalachian hardwood forests. Forest Production Journal, 54:45-51.

Zečić, Z., Krpan, A. P. B., Vukušić, S., 2005: Productivity of $\mathrm{C}$ Holder $870 \mathrm{~F}$ tractor with double drum winch Igland 4002 in thinning beech stands. Croatian Journal of Forest Engineering, 26:49-56.

Zečić, Ž., Vusić, D., Prka, M., Klepac, S., 2010: Utjecaj nagiba traktorskog puta na proizvodnost traktora Timberjack 240C pri privlačenju drvnih sortimenta u preborním šumama. Šumarski list, 134:103-113.

Zečić, Ž., Vusić, D., Nevečerel, H., Mikulin, M., 2011: Utjecaj obujma tovara na proizvodnost traktora Timberjack 240C pri privlačenju debala euroameričke topole u nizinskim šumama. Croatian Journal of Forest Enginnering, 32:357-368.

Zborník výkonových noriem č. 24. Výkonové normy pre sústred'ovanie dreva univerzálnymi, pásovými a špeciálnymi lesnými kolesovými traktormi. Bratislava, Ministerstvo lesného a vodného hospodárstva Slovenskej republiky, 1992, 32 p.

Zelená správa 2007. Bratislava, Ministerstvo pôdohospodárstva Slovenskej republiky, $164 \mathrm{p}$. 